\title{
The origins of symbiosis as a lifestyle in marine crabs (genus Petrolisthes) from the eastern Pacific: Does interspecific competition play a role?
}

\author{
El origen de la simbiosis como hábito de vida en cangrejos marinos (género Petrolisthes) \\ del Pacífico Este: ¿Es importante la competencia inter-específica?
}

\author{
J. Antonio Baeza ${ }^{1}$ \\ ${ }^{1}$ Smithsonian Tropical Research Institute, Apartado Postal 0843-03092, Balboa, Ancón, Republic of Panama. \\ baezaa@si.edu
}

Resumen.- La adopción de un hábito de vida simbiótico representa una de las adaptaciones ambientales más importantes entre los crustáceos marinos. La competencia inter-específica puede ser considerada como un mecanismo importante capaz de explicar la evolución de la simbiosis en este y otros grupos de invertebrados marinos. En el presente estudio se explora el origen histórico del estilo de vida simbiótico en cangrejos marinos (género Petrolisthes) y se examina la importancia de la competencia inter-específica respecto de la evolución de este carácter ecológico. Como marco para este análisis, se utilizó una hipótesis filogenética previamente publicada por otros autores para 29 especies de cangrejos Petrolisthes. Esta hipótesis fue generada utilizando dos métodos de inferencia filogenética (Evolución Mínima y Parsimonia) y la subunidad 16s del ARN ribosomal como marcador genético. Cuando el estilo de vida de cada especie de cangrejo Petrolisthes fue trazado en dicho árbol filogenético, se infirió: i) que el hábito de vida libre representa el carácter ancestral y ii) que el hábito de vida simbiótico evolucionó independientemente al menos dos veces en este grupo de cangrejos. Los cangrejos Petrolisthes que han desarrollado un habito de vida simbiótico ocurren en aguas templadas del hemisferio sur; Allopetrolisthes spinifrons que habita anémonas, y Liopetrolisthes mitra que habita erizos. Un análisis comparativo utilizando el método de contrastes independientes sugirió que la competencia interespecífica no representa un mecanismo importante capaz de explicar la evolución de la simbiosis ni la ocurrencia de asociaciones menos frecuentes entre cangrejos Petrolisthes y otros macro invertebrados marinos. No obstante, la adopción de un hábito de vida simbiótico posee importantes consecuencias para la vida social de los cangrejos que han asumido este estilo de vida.

Palabras clave: Evolución de la simbiosis, competencia, filogenia, método comparativo, Petrolisthes

\begin{abstract}
The adoption of a symbiotic lifestyle is one of the main environmental adaptations in marine crustaceans. Interspecific competition might be considered important in explaining the evolution of symbiosis in this and other groups of marine invertebrates. Here, the historical origin of symbiosis as a lifestyle in marine crabs (genus Petrolisthes) from the eastern Pacific was examined, and the evolutionary role of intra-guild interspecific competition in explaining this ecological trait was explored. A previously published phylogenetic hypothesis for 29 species of Petrolisthes generated by Minimum Evolution and Maximum Parsimony methods of inference (using sequences of 16s rRNA mitochondrial DNA as a genetic marker) was used as framework for this analysis. When the lifestyle of each species was mapped onto the phylogenetic tree for Petrolisthes, a free-living habit was inferred to be the ancestral character state and symbiosis appeared to evolve independently at least twice in this group. Crabs with symbiotic associations occur in temperate waters in the southern hemisphere; Allopetrolisthes spinifrons inhabiting sea anemones, and Liopetrolisthes mitra inhabiting sea urchins. A comparative analysis by independent contrasts suggested that interspecific competition is not important in explaining either the evolution of symbiosis or the occurrence of less frequent partnerships between Petrolisthes crabs and other macroinvertebrates. On the other hand, the adoption of a symbiotic lifestyle has important consequences for the social life of crabs. Symbiotic crabs are proposed as model system to examine the role of the environment in shaping the social behavior of marine invertebrates.
\end{abstract}

Key words: Symbiosis evolution, competition, phylogeny, comparative method, Petrolisthes 


\section{Introduction}

Symbiosis, here defined sensu deBary 1865 (quoted in Vermeij 1983) as dissimilar organisms living together, is common in the marine environment (Ross 1983). Usually, symbiotic associations develop between small organisms (i.e., symbionts) and larger partners that serve as hosts. Symbiotic partnerships may be established among closely (confamiliar species, Boltaña \& Thiel 2001) or distantly related organisms (e.g., zooxanthella and corals, Weis et al. 2001), and can be characterized in terms of the costs and benefits experienced by both partners (i.e., parasitism, commensalism, mutualism), the number of hosts species inhabited by a symbiont (i.e., generalist or specialist), and the degree of host-dependency featured by symbionts (i.e., facultative or obligate). While several studies have explored whether or not symbiotic partners share a common evolutionary history (Cunningham et al. 1991, Distel et al. 1994, Erpenbeck et al. 2002, Gast \& Caron 1996, Griffith 1987, Langer \& Lipps 1995), studies examining the origins of symbioses are uncommon (i.e., Geller \& Walton 2001), and the role of ecological factors accounting for the evolution of this lifestyle remains ill explored.

Mathematical models suggest that the evolution of symbiosis mainly depends upon a trade-off between cost and benefits experienced by either both associates or the one exerting control over the association (Roughgarden 1975). Symbiosis is predicted to evolve whenever the benefits exceed the costs derived from the association or when the net benefits experienced by one of the associates exceed those of alternative lifestyles (i.e., free living) (Roughgarden 1975). Empirical studies have demonstrated that one of the most important benefits derived from hosts by symbiotic organisms is protection against predation (Bloom 1975; Vance 1978). Thus, predation pressure is considered as one of the main evolutionary forces explaining the origins of symbiotic relationships (Vermeij 1983). Similarly, inter-specific competition is seen as another important evolutionary force promoting symbiotic partnerships. Coevolution theory predicts that competition should promote diversity of habitat utilization (i.e. habitat segregation), if the environment provides enough variation in habitat types (Roughgarden 1982). Species of similar requirements are expected to evolve habitat specialization when in sympatry to minimize competition for resources. Although theoretical considerations suggest that habitat specialization slows down as the dimensionality (i.e. the number of species constituting a guild) in the system increases (Roughgarden 1983a, b), noticeable habitat segregation in dimensionally large systems may still occur in environments permanent enough for the coevolutionary process to operate. Usually, competitive interactions increase in magnitude with the size of a guild (i.e., the number of species in a community using similar resources). Therefore, it is possible to hypothesize that the larger the size of a guild, the greater the proportion of symbiotic partnerships that should evolve from the action of intra-guild competitive interactions acting on the past.

Closely related groups of marine organisms featuring different lifestyles (i.e. free-living, symbiotic) and inhabiting environments with differing ecological regimens (i.e. different levels of intra-guild competition) may provide insights into those evolutionary forces (interspecific competition) responsible for the origins of symbiotic lifestyles in the marine environment. In this sense, porcelain crabs from the genus Petrolisthes represent a model system.

Porcelain crabs (including Petrolisthes) are specialized filter-feeders that modify their behavior according to flow conditions (Achituv \& Pedrotti 1999, Valdivia \& Stotz 2006). Active search for positions with adequate water flow for filter-feeding has been proposed for some species (Thiel et al. 2003). Available substrate (e.g. for optimal filtration) has been suggested as the main resource for which sympatric species compete (Hiller et al. 2006). Indeed, interspecific (interference) competition for refuges has been shown to play a role in determining their field distribution (i.e., zonation - Jensen \& Armstrong 1991). In the eastern Pacific, these crabs may be found in intertidal and subtidal rocky shores, mangrovedominated coastal zones, and coral reefs, throughout both temperate and tropical waters (Haig 1960, Stillman \& Reeb 2001, Viviani 1969, Werding \& Haig 1983). This information altogether suggests that different species in the group are subject to varying regimes of interspecific competition. Furthermore, the genus Petrolisthes is known to contain both completely free-living and functionally obligated symbiotic species (Viviani 1969). Yet, other species in the group feature intermediate states of association with macroinvertebrates along a free-living to symbiotic continuum. For example, $P$. armatus develops symbiotic partnerships with other invertebrates only during certain periods of its benthic life (see Campos- 
Gonzáles \& Macías-Chávez 1987). A comparative approach using this group of crabs as a model system may provide insights as to whether or not competition has indeed operated in the past and played a role in the evolution of symbiosis (Felsenstein 1985). However, because phylogenetic relationships are known to bias the strength of environment-trait correlations, a comparison of the lifestyles of a group of organisms must also take into consideration phylogenetic relationships (Harvey \& Pagel 1991).

The aim of the present study is to explore the origins of symbiosis and the role of interspecific competition in explaining the evolution of this ecological trait in Petrolisthes crabs from the eastern Pacific. For this purpose, I used as framework a phylogenetic tree based on a previously published molecular phylogeny of this group generated using Minimum Evolution (ME) and Maximum Parsimony (MP) methods of inference (i.e., Stillman \& Reeb 2001). The lifestyle of Petrolisthes crabs was mapped onto the topology of the Petrolisthes phylogeny to explore the number of independent origins for symbiotic lifestyle in this group. Next, a comparative approach was adopted to examine the role of competition in explaining the evolution of symbiosis within this group of crabs. The results suggest at least two independent origins of symbiosis from the eastern Pacific, but no apparent role for interspecific competition in explaining the evolution of this lifestyle. Nonetheless, the adoption of a symbiotic lifestyle appears to have important consequences for the social life of Petrolisthes. Symbiotic crabs are proposed as model system to examine the role of the environment in shaping the social behavior of marine invertebrates.

\section{Material and methods}

\section{Molecular phylogeny of Petrolisthes}

Here, the historical origin of symbiosis as a lifestyle in Petrolisthes crabs from the eastern Pacific was examined, and the evolutionary role of intra-guild interspecific competition in explaining this ecological trait was explored, using the phylogenetic hypothesis previously published by Stillman \& Reeb (2001). However, additional analyses using Maximum Likelihood and Bayesian methods of inference were considered too (J. A. Baeza, unpublished analyses). Stillman \& Reeb's (2001) hypothesis was generated using Minimum Evolution (ME) and Maximum Parsimony (MP) methods of inference for a total of 29 species of Petrolisthes crabs from the eastern Pacific (see Table 1). Two additional species, one pertaining to the genus Allopetrolisthes and other to the genus Liopetrolisthes, were also included during this study because Stillman \& Reeb's (2001) analysis suggests that the referred species are not supported as separate genera from Petrolisthes. Overall, the analysis by Stillman \& Reeb (2001) recognized two natural groups among Petrolisthes crabs; one corresponding to a "smooth" and other to a "spiny" clade (Fig. 1). These clades that are supported by Stillman \& Reeb’s (2001) molecular phylogeny were first noticed by Haig (1960) who suggested these natural grouping based on morphological features.

\section{Lifestyle characterization of Petrolisthes crabs}

The lifestyle of Petrolisthes crabs was considered as a continuum between a completely free-living and obligate symbiotic habit. In order to have a simple but useful descriptor of the lifestyle featured by crabs within this free-living to symbiotic continuum, a quotient of symbiosis was developed. In addition, a particular species of crab was categorized as symbiotic sensu stricto when the value of the quotient of symbiosis obtained for it was above 0.8 (80\% of the times a species was found dwelling on living substratum of the total number of times the same species was reported in the literature, see below). Species were categorized as free living sensu stricto when the quotient of symbiosis obtained for them was exactly 0 . Species with quotients of symbiosis varying between 0.01 and 0.8 were considered as engaging in "associations" with other macroinvertebrates, but not developing a symbiotic association sensu stricto.

The quotient of symbiosis and the subsequent lifestyle characterization of Petrolisthes crabs were based on early published literature and more recent studies dealing with their autecology. Early studies are mainly of a systematic nature (e.g., Haig 1960) and represent a relevant source of information on certain aspects of the life history in this group. However, most of these studies lack quantitative assessments of the microhabitat used by the species. The sampling methods usually employed by these studies attempted 


\section{Table 1}

Petrolisthes crabs from the eastern Pacific. Shown are the quotient of symbiosis (Q.S., mean $[X] \pm$ standard deviation [s.d.]), the average number of congeners present throughout the range of distribution of a particular species of crab (Guild size [G.S.], $X \pm$ s.d.), the number of studies and total sampling locations on which the quotient of symbiosis is based (S/L), and the references from where information was taken when calculating the quotient of symbiosis for each one of the species considered during the present study. Species in bold are considered as symbiotic sensu stricto during the present study

Cangrejos Petrolisthes del Pacífico Este. Se muestra el cuociente de simbiosis (Q.S., promedio [X] \pm desviación estándar [s.d.]), el promedio del número de especies congenéricas presentes a lo largo del rango de distribución de una especies de cangrejo en particular (tamaño del ensamble [G.S.], X \pm s.d.), el número de estudios y el número total de lugares muestreados en los que basó el cálculo del cuociente de simbiosis (S/L), y las referencias desde las cuales la información fue tomada para el cálculo del cuociente de simbiosis. Las especies en negrillas son consideradas simbiontes sensu stricto durante el presente estudio

\begin{tabular}{|c|c|c|c|c|}
\hline Species & Q.S. & G.S. & $\mathrm{S} / \mathrm{L}$ & References \\
\hline P. armatus & $21.2 \pm 23.5$ & $12.83 \pm 5.19$ & $54(6)$ & $1,4,7,12,16,19$ \\
\hline P. cinctipes & $0 \pm 0$ & $1.75 \pm 0.96$ & $5(3)$ & 1,11 \\
\hline P. eriomerus & $3.5 \pm 4.9$ & $2.4 \pm 1.67$ & $42(2)$ & 1,11 \\
\hline P. manimaculis & $0 \pm 0$ & $6 \pm 3$ & $32(1)$ & 1 \\
\hline P. cabrilloi & $0 \pm 0$ & $6.5 \pm 2.12$ & $59(3)$ & $1,4,8$ \\
\hline P. crenulatus & $59.1 \pm 45.1$ & $19 \pm 0$ & $30(3)$ & $1,4,18$ \\
\hline P. gracilis & $8.9 \pm 13.9$ & $18.33 \pm 2.08$ & $57(3)$ & $1,4,19$ \\
\hline P. tiburonensis & $0 \pm 0$ & $9 \pm 7.07$ & $19(2)$ & 1,4 \\
\hline P. sanfelipensis & $16.7 \pm 28.8$ & $13.5 \pm 7.78$ & $16(3)$ & $1,4,16$ \\
\hline P. hirtipes & $8.3 \pm 14.4$ & $7.33 \pm 2.08$ & $35(4)$ & $1,4,16$ \\
\hline P. laevigatus & $0 \pm 0$ & $5.5 \pm 4.12$ & $10(4)$ & $1,3,5,17$ \\
\hline P. tuberculatus & $1.47 \pm 2.9$ & $8.17 \pm 0.75$ & $20(4)$ & $1,3,5,17$ \\
\hline P. violaceus & $0 \pm 0$ & $8.17 \pm 0.75$ & $19(5)$ & $1,3,5,14,16$ \\
\hline A. angulosus & $3.16 \pm 7.1$ & $7.14 \pm 2.79$ & $23(5)$ & $1,3,5,14,17$ \\
\hline P. granulosus & $0 \pm 0$ & $7.14 \pm 2.79$ & $16(3)$ & $1,5,17$ \\
\hline L. mitra & $83.3 \pm 40.8$ & $6.6 \pm 2.97$ & $12(5)$ & $1,4,6,15,19$ \\
\hline A. punctatus & $0 \pm 0$ & $8.17 \pm 0.75$ & $3(3)$ & $1,3,5$ \\
\hline P. schmitti & $25 \pm 35.4$ & $9.67 \pm 4.93$ & $15(2)$ & 1,4 \\
\hline A. spinifrons & $81.8 \pm 40.7$ & $8.17 \pm 0.75$ & $15(5)$ & $1,3,5,8,14$ \\
\hline P. tuberculosus & $0 \pm 0$ & $7.5 \pm 2.26$ & $3(3)$ & $1,5,17$ \\
\hline P. agassizii & $36.3 \pm 43.1$ & $13.33 \pm 4.63$ & $34(4)$ & $1,10,16,19$ \\
\hline P. edwardsii & $33.8 \pm 34.9$ & $14.67 \pm 2.73$ & $29(7)$ & $1,4,10,12,16,18,19$ \\
\hline P. galathinus & $0 \pm 0$ & $13.33 \pm 6.66$ & $35(2)$ & 1,16 \\
\hline P. haigae & $72.4 \pm 19.7$ & $16.29 \pm 4.54$ & $82(5)$ & $1,10,16,18,19$ \\
\hline P. holotrichus & $0 \pm 0$ & $10.5 \pm 6.36$ & $22(2)$ & $1,16,19$ \\
\hline P. lewisi austrinsus & $0 \pm 0$ & $14.67 \pm 2.73$ & $9(4)$ & $1,2,16,19$ \\
\hline P. platymerus & $0 \pm 0$ & $17.5 \pm 2.12$ & $10(4)$ & $1,14,16,19$ \\
\hline P. cf. tridentatus & $0 \pm 0$ & $14 \pm 5.59$ & $37(4)$ & $1,10,16$ \\
\hline P. zacae & $0 \pm 0$ & $17.5 \pm 2.12$ & $2(2)$ & 13,16 \\
\hline
\end{tabular}

1.- Haig (1960 and references therein); 2.- Villalobos et al. (1989); 3.- Viviani (1969); 4.- Correa-Sandoval \& Rodríguez-Cortéz (1998); 5.- Villarroel (1989); 6.- Weber (1991), Weber \& Galleguillos (1991); 7.- Campos-Gonzáles \& Macías-Chávez (1987); 8.- Kropp (1981); 9.- Stuardo (1962); 10.Werding \& Haig (1983); 11.- Ricketts et al. (1985); 12.- Brusca (1980); 13.- Gore \& Abele (1976); 14.- Baeza \& Stotz (1998, 2003); 15.- Baeza \& Thiel (2000); 16.- Gore (1982); 17.- Antezana et al. (1965); 18.- García-Madrigal (1999); 19.- Haig (1968) 


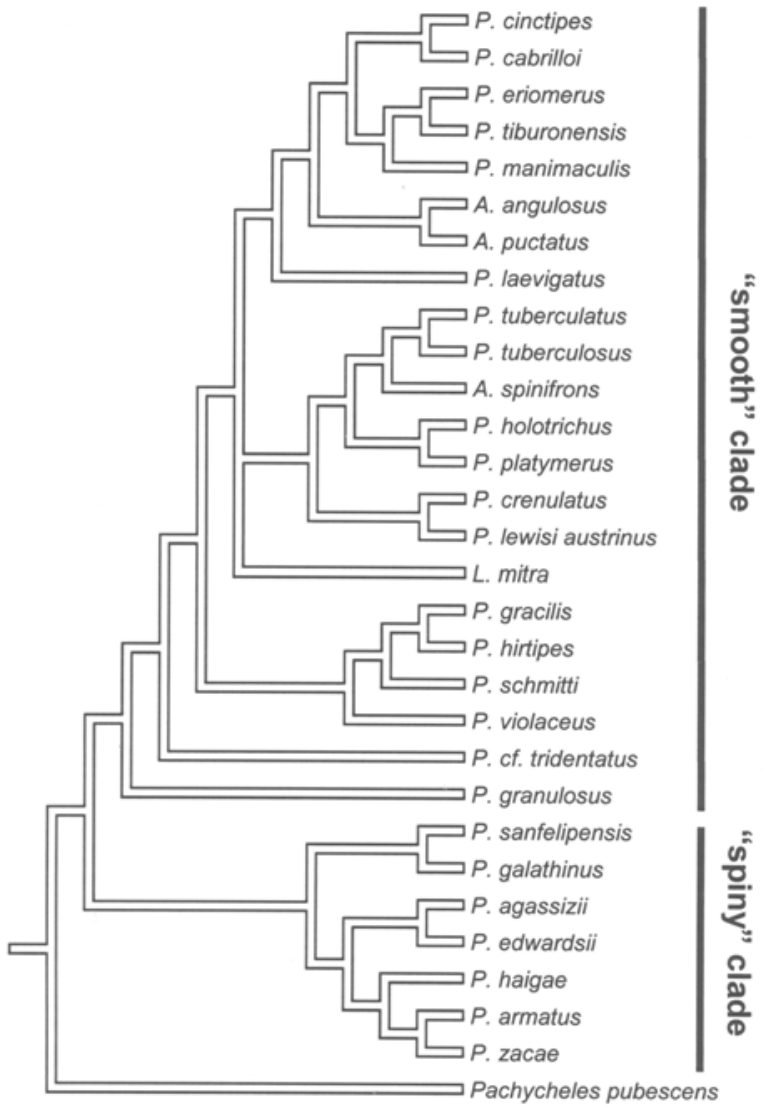

Figure 1

Phylogenetic hypothesis for Petrolisthes crabs from the Eastern Pacific following Stillman \& Reeb (2001). The tree shows the "smooth" and "spiny" clade first noticed by Haig (1960) based on morphological characters and then supported by the molecular phylogenetic analysis. $A$ = Allopetrolisthes, $L=$ Liopetrolisthes, $P=$ Petrolisthes

Hipótesis filogenética de los cangrejos Petrolisthes del Pacífico Este basada en Stillman \& Reeb (2001). El árbol muestra los clados "liso" y "espinoso" inicialmente notados por Haig (1960) basándose en caracteres morfológicos y

luego apoyado por caracteres moleculares. $A=$

Allopetrolisthes, $L=$ Liopetrolisthes, $P=$ Petrolisthes

to maximize the number of specimens collected per sampling event, rather than obtaining information on the microhabitat used by the collected specimens. Sampling methodology and the descriptive nature of early studies most probably resulted in artificially diminishing the recognition of symbioses between
Petrolisthes crabs and other macro invertebrates when this lifestyle was especially infrequent and/or facultative. The above does not hold true for more recent studies that usually provide accurate information on microhabitat-use due to their quantitative or semiquantitative nature.

In order to include relevant information from early studies, but to reduce the error of the estimate, all of the information on the lifestyle of Petrolisthes crabs retrieved from early studies (Haig [1960] and previously published studies referred therein and summarized on her Appendix 1) was given a weight equal to that assigned to the information retrieved from each one of the studies published after Haig (1960). First, I calculated the quotient of symbiosis from the information available in Haig (1960, her Appendix 1). This quotient of symbiosis was estimated as the number of sampling sites where specimens of a particular species were found associated with any type of living substratum (i.e. sponges, corals, sea anemones, sea urchins) divided by the total number of sampling sites from where crabs of the species in question were collected. Next, the process above was repeated for any other study published after Haig (1960) containing information on the habitat of the studied species. All of these quotients were integrated into a data base from which a definitive average (i.e. mean) quotient of symbiosis was calculated (Table 1 ).

\section{Origins of the symbiotic life-style in Petrolisthes crabs}

To explore the ancestral lifestyle of Petrolisthes crabs from the eastern Pacific, and to test whether or not symbiosis in this group originated once or multiple times, the lifestyle evolution of Petrolisthes crabs was parsimoniously reconstructed using MacClade v. 3.06 (Maddison \& Maddison 2000). The previously published phylogenetic hypothesis by Stillman \& Reeb (2001) was used as framework when reconstructing the evolution of lifestyles in this group of crabs. During character reconstructions the quotient of symbiosis was considered as a continuous or discrete character.

When this character was considered continuous, lifestyle evolution was reconstructed using linear parsimony (Maddison \& Maddison 2000). Linear parsimony was preferred over squared-change parsimony because the latter minimizes the sum of the square of the evolutionary change on each branch of the evolutionary tree, forcing changes to spread out 
more evenly over the tree. This implies that squaredchange parsimony tends to propose change where none is required, as compared to linear parsimony (Maddison \& Maddison 2000). In contrast, linear parsimony minimizes the sum of the absolute value of evolutionary change on the branches of the phylogenetic tree, and considers only the three closest nodes in order to calculate the ancestral node. This implies that linear parsimony reconstructions usually result in ambiguities for several nodes, due to multiple, equally parsimonious optimizations (Maddison \& Maddison 2000). This ambiguity was partially included in the analysis of character reconstruction when resolving ambiguous nodes by considering only the minimum (MacClade option MINSTATE) or maximum (MacClade option MAXSTATE) value of the set of equally parsimonious values observed at each ambiguous node.

When the quotient of symbiosis was considered discrete, it was first recoded and then overimposed as a multi-state ordered character onto the molecular phylogeny of the group. As with linear parsimony, multiple, equally parsimonious optimizations result when a multi-state ordered character is reconstructed (Maddison \& Maddison 2000). This ambiguity was partially considered in the analysis, this time by applying the ACTRAN (which accelerates changes toward the root) and DELTRAN (which delays changes away from the route) functions to resolve values on ambiguous nodes.

\section{The role of intra-guild competition in the origins of symbiosis}

According to the rationale developed in the introduction, in the case intra-guild competitive pressure is a significant evolutionary force in explaining the adoption of a symbiotic lifestyle in Petrolisthes crabs, the proportion of species developing symbiotic associations with other macroinvertebrates in a guild should increase with the guild size (i.e., with an increase in the number of congeneric species composing that guild). In contrast, the proportion of species developing symbiosis should not vary accordingly with the guild size if competition does not play an important role in the evolution of symbiosis.
The prediction above was tested by determining whether or not the quotient of symbiosis progressed from a small value with low variability in magnitude (for species with a relatively small mean number of sympatric congeners present throughout the range of distribution) to another value highly variable in magnitude (for species with a relatively large mean number of sympatric congeners). It must be noticed that a strong correlation between quotient of symbiosis and mean number of congeners present throughout the range of distribution of a particular species is not predicted, since that would assume that when intraguild interspecific competition was high, all of the species constituting that guild developed a symbiotic lifestyle. Instead, the prediction states that a higher proportion of species will develop a symbiotic lifestyle when intra-guild competition is high, rather than when low. Thus, the relationship between the quotient of symbiosis and guild size should be polygonal as opposed to linear.

To estimate the average number of congeneric species present throughout the range of distribution of a particular Petrolisthes species, I first obtained from the literature the range of distribution for each one of the 46 species of Petrolisthes reported for the region (Carvacho 1985, Gore 1982, Haig 1960, Werding \& Haig 1983). Next, the eastern Pacific coast of America was divided into bands of $5^{\circ}$ latitude each and the number of Petrolisthes species present in each band was calculated. Finally, I calculated the total number of species present in each latitudinal band through the geographical range of distribution for each one of the 29 species analyzed.

The relationship between the quotient of symbiosis and guild size was explored by correcting for phylogenetic effects using independent contrasts (Felsenstein 1985). Independent contrasts were generated using the CAIC software package (Purvis \& Rambaut 1995) and the results of PAUP and MrBayes analyses (not shown here). Required branch lengths for the analysis were obtained both from ML and Bayesian phylogenetic inferences. 

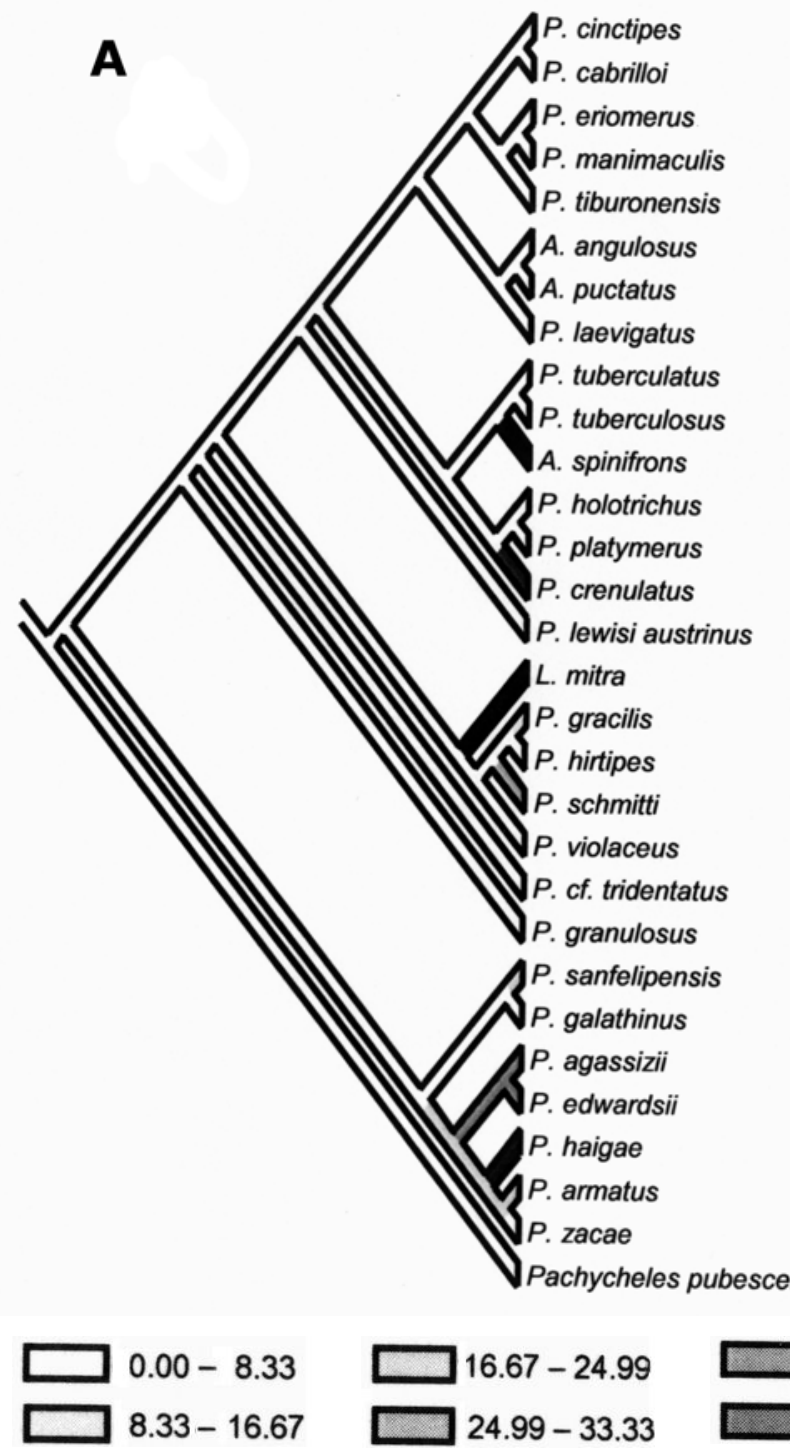

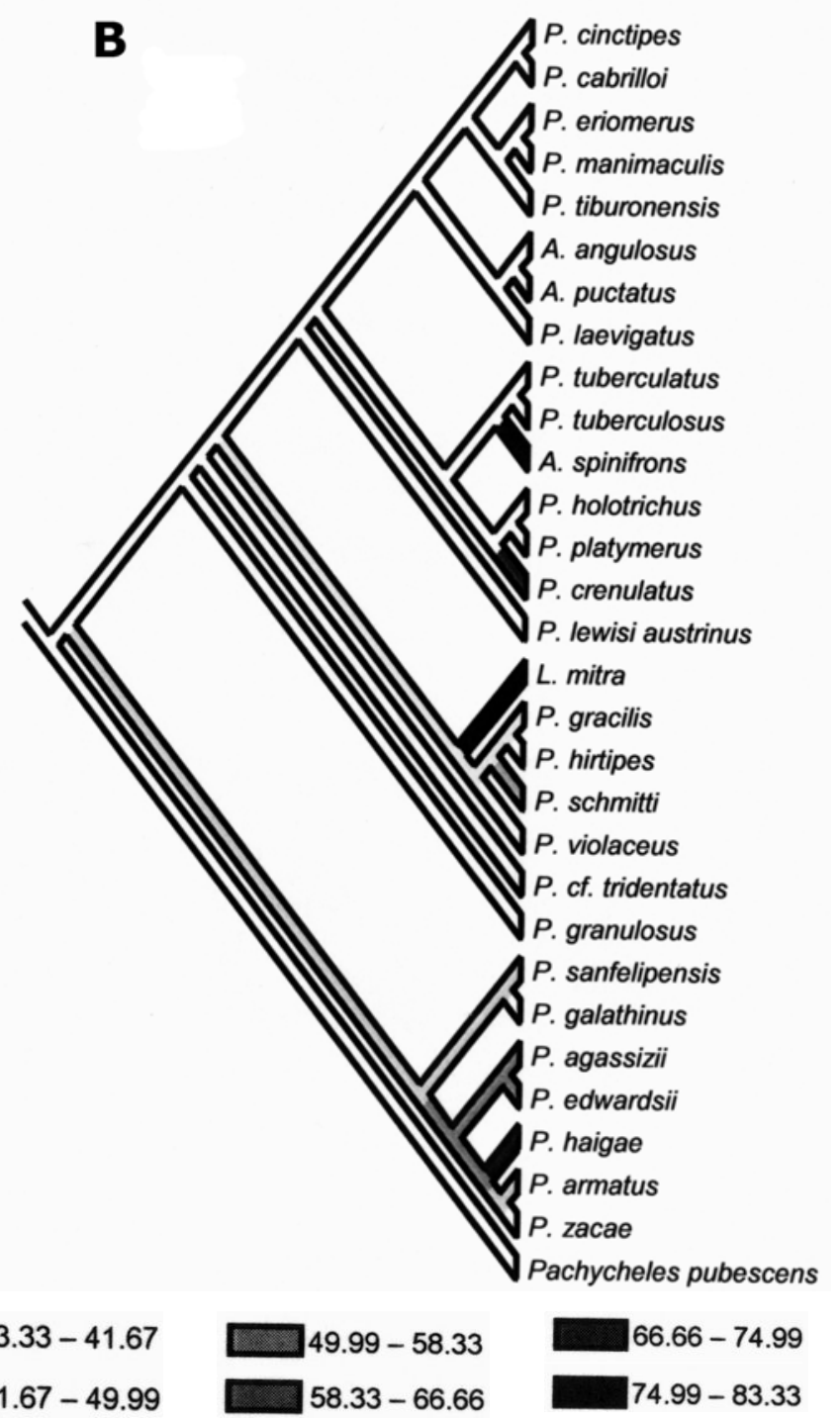

Figure 2

Petrolisthes crabs from the Eastern Pacific. The evolution of the symbiotic life-style traced on the the phylogenetic tree based on Stillman \& Reeb (2001) using Pachycheles pubescens as outgroup. (A) Character considered continuous, and node ambiguities resolved with MINSTATE option. Similar results were obtained when the character was considered discrete, and node ambiguities were resolved with ACTRAN option (not shown). (B) Character considered continuous, and node ambiguities resolved with MAXSTATE option. Similar results were obtained when the character was considered discrete, and node ambiguities were resolved with DELTRAN option (not shown)

Cangrejos Petrolisthes del Pacífico Este. La evolución del estilo de vida simbiótico se encuentra trazado en el árbol filogenético basado en Stillman \& Reeb (2001). La especie de cangrejo Pachycheles pubescens es utilizada como grupo hermano para el análisis. (A) Carácter considerado continuo, y ambigüedad en los nodos resuelta con la opción MINSTATE. Un resultado similar es obtenido cuando el carácter es considerado discreto y la ambigüedad en los nodos es resuelta con la opción ACTRAN (no mostrado). (B) Carácter considerado continuo y ambigüedad en los nodos resuelta con la opción MAXSTATE. Un resultado similar se obtiene cuando el carácter es considerado discreto y la ambigüedad en los nodos es resuelta con la opción DELTRAN (no mostrado) 


\section{Results}

\section{Lifestyle and evolution of symbiosis in Petrolisthes crabs}

Based on the review of the literature and the discrete categorization of the lifestyle of Petrolisthes crabs, only two species were considered as symbiotic sensu stricto. Both species are found in temperate waters of the southern hemisphere: Allopetrolisthes spinifrons dwelling on the sea anemones Phymactis clematis and Phymanthea pluvia (see Haig 1960, Stuardo 1960, Baeza et al. 2002), and Liopetrolisthes mitra dwelling on the sea urchin Tetrapygus niger (see Haig 1960, Baeza \& Thiel 2000). Three additional species were found to associate relatively frequently (between 33.8 and $72.4 \%$ of the times) with other macroinvertebrates in their natural habitat. Among them, $P$. haigae inhabit coral heads of Pocillopora spp. in tropical waters (Haig 1960 [as P. marginatus], Werding \& Haig 1983), P. crenulatus occasionally found in coral heads, and P. agassizii and P. edwardsii both occasionally associate with corals and sponges (Werding \& Haig 1983). All of the species above that form associations with other macroinvertebrates are from tropical waters. Among those species featuring very low quotients of symbiosis, $P$. armatus is of particular interest, because it has been reported as a commensal of the limpet Crucibulum (Crucibulum) spinosum during its early life benthic phase (CamposGonzáles \& Macías-Chávez 1987), but was not considered as symbiotic in the present study based on habitat occupation by their adults, which are usually found among rocks or within crevices (Haig 1960).

Similar scenarios for the evolution of lifestyles in Petrolisthes crabs from the eastern Pacific were obtained when the quotient of symbiosis was parsimoniously mapped as a continuous or discrete character state, and ambiguous nodes were resolved using the MINSTATE or ACTRAN option, respectively. These character reconstructions consistently indicate that a free living lifestyle is the ancestral condition for the group (Fig. 2A). The symbiotic lifestyle featured by $L$. mitra and $A$. spinifrons represents two independent evolutionary events. A degree of association with other macroinvertebrates appears to have evolved as a trait in the common ancestor of $P$. agassizii, $P$. edwardsii, $P$. haigae, P. armatus, and P. zacae. This trait appears to have gradually progressed within this clade, expressing to a maximum in $P$. haigae. The free living lifestyle of
$P$. zacae represents a secondary loss of the increasing trend of association with other macroinvertebrates observed in this clade (Table 1).

A second scenario for the evolution of lifestyles in Petrolisthes, somewhat different from the above, was indicated when the quotient of symbiosis was parsimoniously mapped as a continuous or discrete character state, and ambiguous nodes were resolved using the MAXSTATE or DELTRAN option, respectively (Fig. 2B). Again, a free living lifestyle was inferred as the ancestral condition for the group, and the symbioses featured by A. spinifrons and L. mitra each represent independent evolutionary events one from one another. However, with regards to L. mitra, the association with other macroinvertebrates as a trait appears to have evolved in the common ancestor of this last species, $P$. gracilis, $P$. hirtipes, $P$. schmitti, and $P$. violaceus, to be then secondarily lost in $P$. hirtipes and $P$. violaceus. Association with other macroinvertebrates as a trait also evolved in the common ancestor of $P$. sanfelipensis, P. galathinus, P. agassizii, P. edwardsii, $P$. haigae, $P$. armatus, and $P$. zacae. In this last clade, the tendency to associate with macroinvertebrates gradually progressed, and reached its maximum expression in $P$. haigae. A regression of the trait occurred in $P$. armatus, while a secondary loss occurred in $P$. galathinus and $P$. zacae. In this scenario, taxa developing at least some degree of association with other macroinvertebrates appear to be clustered mainly in two clades, as opposed to the first scenario.

\section{Interspecific competition as an evolutionary force}

Species richness of Petrolisthes crabs from the eastern Pacific follows a multimodal pattern with latitude (Fig. 3 ), as indicated when plotting the presence/absence of each one of the 46 species reported from the region onto latitudinal bands of $5^{\circ}$ (Haig 1960, Werding \& Haig 1983). From north to south, a first peak of richness is localized approximately at $20-25^{\circ} \mathrm{N}$, but this peak is due to the combined species of Petrolisthes recorded from the west coast of Baja California and the Sea of Cortez. A second peak of species richness occurs in tropical waters off Central America, between $10^{\circ} \mathrm{N}$ and $5^{\circ} \mathrm{N}$, where a maximum of 21 species has been reported. The third peak is less accentuated than the previous two, and occurs at $15-35^{\circ} \mathrm{S}$, off the coasts of Chile and Peru, where a maximum of 10 species are found. 
Visual inspection of the range of distribution exhibited by the studied species indicates that both species adopting a symbiotic lifestyle do not inhabit environments with a large number of sympatric congeners throughout their range of distribution (Fig. 3). On the other hand, when these two symbiotic crabs are not considered, the proportion of species featuring association with macro invertebrates slightly increase with an increase in the average number of congeners present throughout their range of distribution (Fig. 4A). None of the species with less than 5 sympatric congeners throughout their range of distribution was

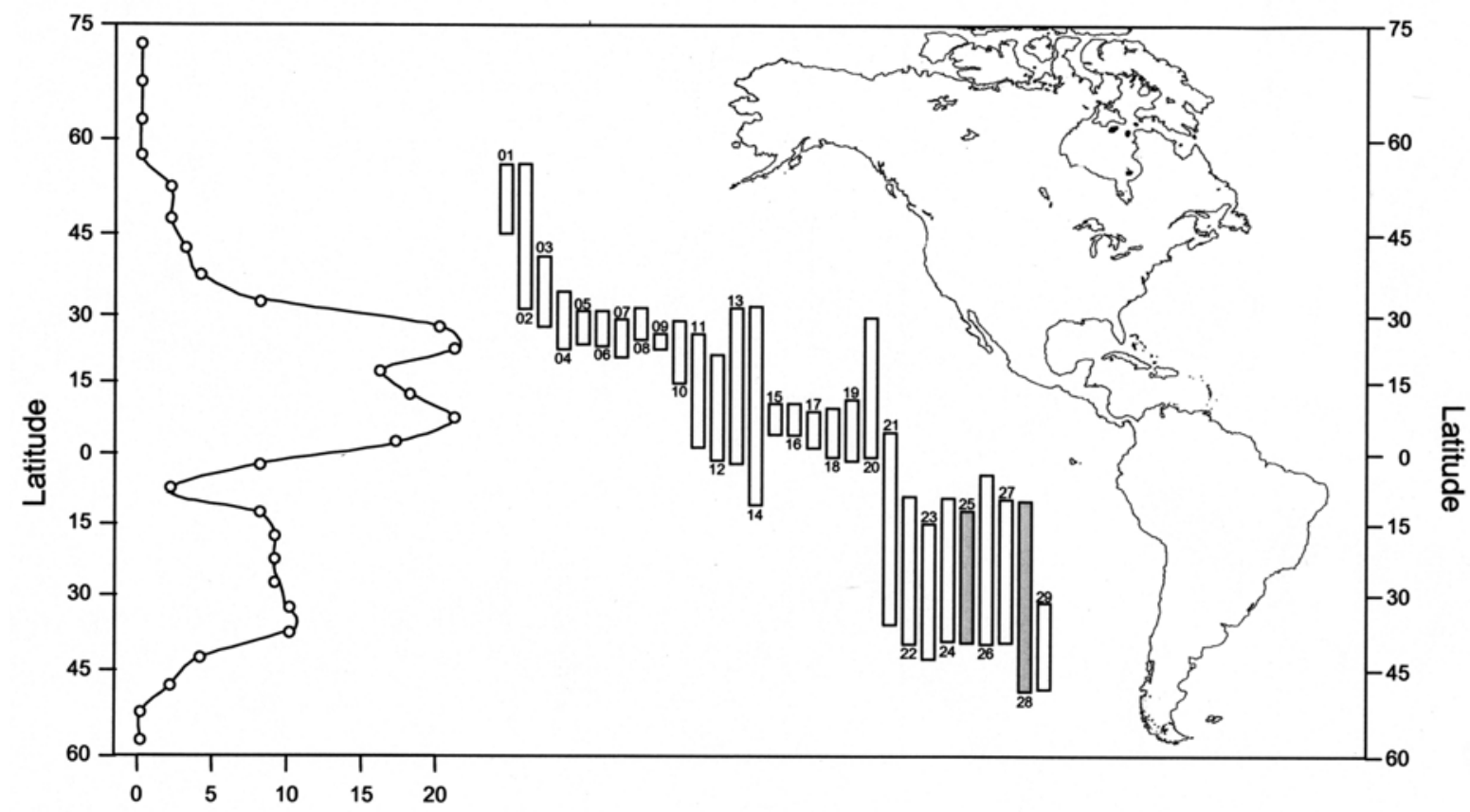

Species Richness Distribution

Petrolisthes

Figure 3

Species richness (left side of the figure) of Petrolisthes crabs from the Eastern Pacific (for latitudinal bands each of $5^{\circ}$ ), and range of distribution (bands at center of the figure) for the $\mathbf{2 9}$ species studied herein. Numbers correspond to species in the following order: 1, Petrolisthes cinctipes; 2, P. eriomerus; 3, P. manimaculis; 4, P. cabrilloi; 5, P. tiburonensis; 6, P. schimitti; 7, P. crenulatus; 8, P. sanfelipensis; 9, P. hirtipes; 10, P. gracilis; 11, P. edwardsii; 12, P. agassizii; 13, P. haigae; 14, P. armatus;

15, P. platymerus; 16, P. zacae; 17, P. holotrichus; 18, P. galathinus; 19, P. tridentatus; 20, P. lewisi austrinus; 21, $P$. granulosus; 22, P. tuberculatus, 23, P. tuberculosus, 24, Allopetrolisthes punctatus; 25, A. spinifrons; 26, A. angulosus; 27, Petrolisthes violaceus; 28, Liopetrolistes mitra; 29, Petrolisthes laevigatus. Shaded bands correspond to species characterized as symbiotic sensu stricto during the present study

Riqueza de especies (lado izquierdo de la figura) de cangrejos Petrolisthes del Pacífico Este (para bandas latitudinales de $5^{\circ}$ ) y rango de distribución (bandas al centro de la figura) de las 29 especies utilizadas durante el presente estudio. Los números corresponden a las diferentes especies en el siguiente orden: 1 , Petrolisthes cinctipes; 2, P. eriomerus; 3, P. manimaculis; 4, P. cabrilloi; 5, P. tiburonensis; 6, P. schimitti; 7, P. crenulatus; 8, P. sanfelipensis; 9, P. hirtipes; 10, P. gracilis; 11, P. edwardsii; 12, P. agassizii; 13 P. haigae; 14, P. armatus; 15, P. platymerus; 16, P. zacae; 17, P. holotrichus; 18, P. galathinus; 19, P. tridentatus; 20, P. lewisi austrinus; 21, P. granulosus;, 22, P. tuberculatus, 23, P. tuberculosus, 24, Allopetrolisthes punctatus; 25, A. spinifrons; 26, A. angulosus; 27, Petrolisthes violaceus; 28, Liopetrolistes mitra; 29, Petrolisthes laevigatus. Las bandas achuradas corresponden a las especies caracterizadas como simbiontes sensu stricto durante el presente estudio 

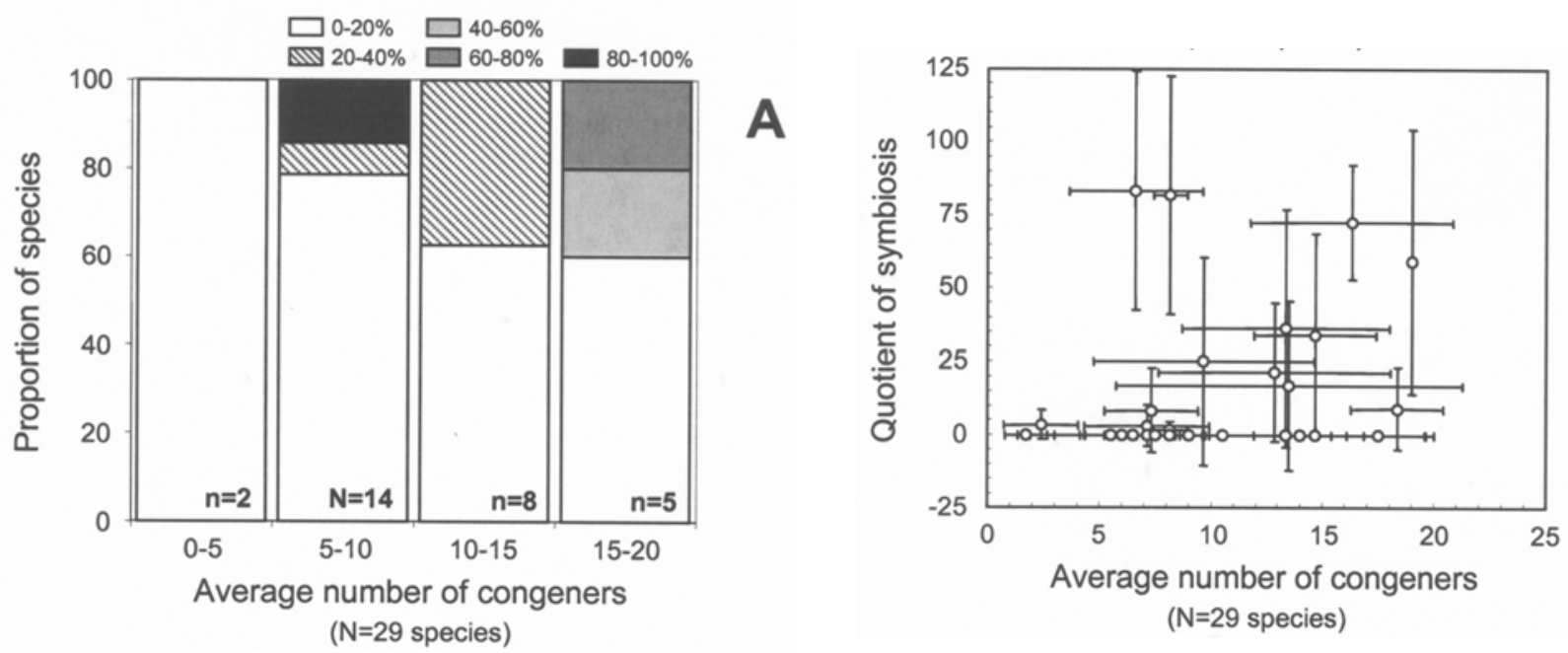

B

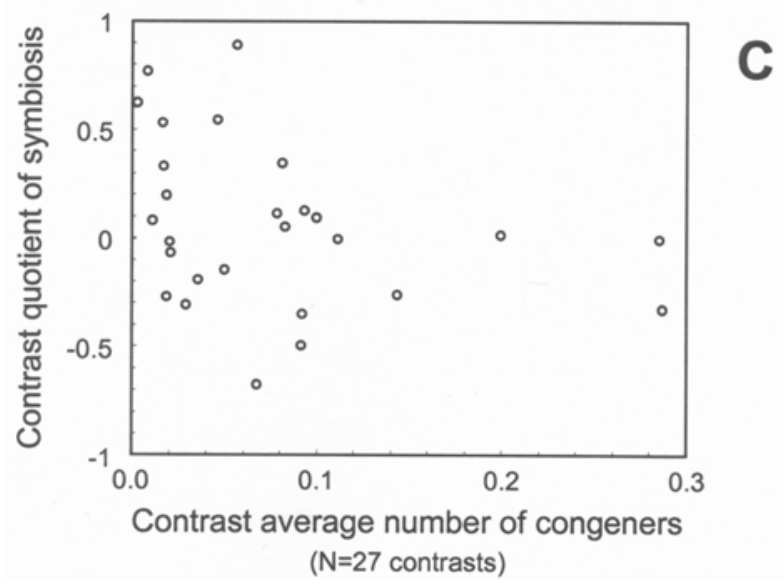

Figure 4

Petrolisthes crabs from the Eastern Pacific. (A) Frequency of occurrence of species featuring different ranges of association with macro invertebrates (quotient of symbiosis) on guild of different sizes (different mean number of congeneric species present throughout the range of distribution of a particular species). (B) The relationship between the quotient of symbiosis and mean number of congeners present throughout the range of distribution of a particular species (i.e. guild size). (C) The relationship between contrast of the quotient of symbiosis and contrast of the mean number of congeners present throughout the range of distribution of a particular species. Independent contrasts were generated with information from the phylogenetic analysis of Stillman and Reeb (2001)

Cangrejos Petrolisthes del Pacífico Este. (A) Frecuencia de ocurrencia de las especies que desarrollan diferentes grados de asociación con otros macro invertebrados (cuociente de simbiosis) en ensambles (comunidades) de diferentes tamaños (número de especies congenéricas presentes a lo largo del rango de distribución de una especie en particular). (B) La relación entre el cuociente de simbiosis y el número promedio de especies congenéricas presentes a lo largo del rango de distribución de una especie en particular

(i.e. tamaño del ensamble). (C) La relación entre el contraste del cuociente de simbiosis y el contraste del número promedio de especies congenéricas presentes a lo largo del rango de distribución de una especie en particular. Los contrastes se generaron con la información del árbol filogenético basado en Stillman \& Reeb (2001) 
found to associate with other macro invertebrates. The quotient of symbiosis evolved from a small value in magnitude and with low variability in species comprising small guilds (i.e. with a relatively small number of congeners throughout their range of distribution) to a value that varies in magnitude among species comprising relatively large guilds (Fig. 4B). However, the lack of association between the quotient of symbiosis and guild size became apparent when correcting for phylogenetic effects (Fig. 4C). No significant correlations between the contrast of quotient of symbiosis and the contrast of guild size was found when contrasts of the above variables were generated ( $\mathrm{r}$ $=0.01, \mathrm{P}>0.05)$. The information above suggests that intra-guild competitive pressure, as measured during the present study, does not represent an important evolutionary force explaining the origins of symbiosis in Petrolisthes crabs from the Eastern Pacific.

\section{Discussion}

\section{Multiple origins of symbiosis in Petrolisthes crabs}

The present analysis suggests that (1) a free living lifestyle is the ancestral condition in Petrolisthes crabs from the eastern Pacific, (2) two independent origins of symbiosis have occurred in Petrolisthes (sensu lato) crabs from the eastern Pacific (Allopetrolishes spinifrons and Liopetrolisthes mitra), (3) the adoption of a symbiotic lifestyle in L. mitra may be predated by an ancestral tendency to associate occasionally with other macroinvertebrates, as suggested by one of the most parsimonious lifestyle reconstructions, and (4) the reversion of the tendency to occasionally associate with other macro invertebrates to a completely free living lifestyle may have happened once or a maximum of four times (i.e. in Petrolisthes zacae, $P$. galathinus, $P$. hirtipes, and $P$. violaceus). Although almost three quarters of the Petrolisthes species described from the eastern Pacific were considered in the present analysis, the incorporation of additional species may result in a larger number of independent origins of symbiosis in this group. For instance, $P$. glasselli, which was not included in this analysis, has invariably been cited as an inhabitant of coral heads (Haig 1960, Werding \& Haig 1983). Morphological characters suggest that $P$. glasselli pertain to the "spiny" clade of Petrolisthes, where symbiosis sensu stricto was not found in the present study. Similarly, Liopetrolisthes patagonicus reported as an associate of sea urchins and sea stars was not included in the present analysis (Weber 1991).
Morphological and genetic (i.e., protein electrophoresis profiles) characters suggest that $L$. patagonicus is a sibling species of L. mitra (Weber \& Galleguillos 1991). Nonetheless, additional studies are required to clarify the phylogenetic position of $L$. patagonicus within the genus Petrolisthes (sensu lato). In general, two evolutionary independent origins of symbiosis for Petrolisthes crabs from the eastern Pacific may be interpreted as a minimum number of possible evolutionary events. The same may hold true for reversals from a symbiotic condition to a free living lifestyle.

Although no crabs from tropical waters were found to develop symbioses sensu stricto with other macroinvertebrates, the analysis suggest that the principal pattern of evolutionary change within the predominantly tropical "spiny" clade of Petrolisthes is toward an increase in the frequency of association with other macroinvertebrates. The relatively high frequency of association with sponges reported for $P$. haigae may be interpreted as an ongoing process of symbiotic specialization. The same may hold true for $P$. crenulatus pertaining to the "smooth" clade. Nonetheless, additional information about the autecology of $P$. haigae and $P$. crenulatus is required to determine whether or not they can be considered as facultative symbionts.

\section{Does interspecific competition play a role?}

The association found between guild size and quotient of symbiosis suggested at first glance a role for competition in explaining the evolution of symbiosis in Petrolisthes crabs from the eastern Pacific. However, when correcting for phylogenetic effects, any association between the referred variables suggesting that competition was important was lost. The present study indicates the importance of correcting for phylogenetic effects when testing for the effect of evolutionary forces in explaining diversity on ecological traits found in present-day guilds. Recent studies in other groups of marine organisms have concluded that particular traits are sensitive to natural selection whenever the traits are found to have multiple origins (i.e., Geller \& Walton 2001). Although a trait may well be sensitive to natural selection, comparative analyses that correct for phylogenetic effects are required before claiming that a trait is an adaptation to specific sets of ecological conditions. 
Many ecological studies demonstrate the important role that competition plays in structuring present day communities (Roughgarden 1982 and references therein). However, the role of competition in an evolutionary context still remains unclear. For instance, several historical studies, including the present one, have failed to find a correlation between proxies of competitive pressure and phenotypic traits thought to be shaped by this factor (e.g., Losos 1990, Schluter 1996). On the other hand, various other comparative studies have supported the importance of competitive interactions in determining behavioral and morphological novelties in groups of closely related species (see Duffy et al. 2000, Giannasi et al. 2000). So far, interspecific competition does appear to be an important, but not universal, evolutionary force explaining phenotypic divergence among closely related sympatric species.

Predation pressure as a factor explaining the evolution of symbiosis in Petrolisthes crabs remains to be explored. Since predation is thought as heavier in the tropics than in temperate environments, an increase in the proportion of species featuring symbiotic lifestyles should be observed with a decrease in latitude. At first glance, the present study does not support this idea. Both species described here as symbiotic sensu stricto inhabit temperate environments. The study of the diet in several guilds of predatory fish and crab species occurring both in temperate and tropical environments may be used as a proxy of predation pressure. It would then be possible to estimate the importance of predation as evolutionary force favoring symbiotic life-styles in this guild of marine crabs by using the comparative approach. Experimental studies determining the effect of host availability on the propensity of crabs to suffer predation by fish or other crabs should also improve our understanding of those forces explaining the evolution of symbiosis as a lifestyle in Petrolisthes crabs.

At last, it must be acknowledged that the number of congeners co-occurring in a geographical region represents a coarse index of interspecific competitive pressure. Sympatric species at larger spatial scales (degrees of latitude) may turn out to be allopatric (segregated by habitat) at shorter spatial scales (meters or kilometers). Under this scenario, species richness may not necessarily correlate well with interspecific competitive pressure. This coarse index of interspecific competition may alternatively explain the lack of association between guild size and quotient of symbiosis observed in the present study.

\section{Consequences for the lifestyle of symbiotic crabs}

The adoption of a symbiotic lifestyle might have important consequences for the social behavior of symbionts if key characteristics of the newly adopted habitat (host) differ from the ancestral one. To explore this notion, socioecological attributes of both symbiont Petrolisthes crabs and their closest free living relatives were summarized together with characteristics of their habitat (Table 2). The microhabitat used by free living species (i.e. crevices) is complex in structure, large in

Table 2

Socioecological and habitat characteristics of Petrolisthes crabs considered symbionts sensu stricto and their closest relatives. Phylogenetic relationships between the species were inferred from the tree on Fig. 1

Características socio-ecológicas y del hábitat en cangrejos Petrolisthes considerados simbiontes sensu stricto durante el presente estudio y de las especies filogenéticamente relacionadas. La relación filogenética entre las especies se infirió a partir del árbol presentado en la Fig. 1

\begin{tabular}{|c|c|c|c|}
\hline Species & Status & Socioecology & Host / Habitat characteristics \\
\hline A. spinifrons $^{1,3}$ & Symbiont & Solitary & Simple, small, scarce \\
\hline P. tuberculatus ${ }^{1,2}$ & Free living & Gregarious & Complex, large, abundant \\
\hline P. tuberculosus ${ }^{1,2}$ & Free living & Gregarious & Complex, large, abundant \\
\hline L. mitra $^{1,4}$ & Symbiont & Gregarious & Complex, large, abundant \\
\hline P. violaceus ${ }^{1,2}$ & Free living & Gregarious & Complex, large, abundant \\
\hline
\end{tabular}

Note.- 1. Antezana et al. (1965), 2. Villarroel (1989), 3. Baeza et al. (2001), 4. Baeza \& Thiel (2003) 
size, and abundant. For L. mitra, host characteristics are similar to those of the habitat used by its closest extant relatives (and most probably its ancestor). The host sea urchins of L. mitra are abundant, morphologically complex, and relatively large in size (Baeza \& Thiel 2003). No differences in socioecological characteristics are observed between L. mitra and its free-living closest relatives. All of these species inhabit their microhabitats as unstructured aggregations (Baeza \& Thiel 2000). In contrast, the sea anemones inhabited by A. spinifrons are scarce and represent morphologically simple and small refuges (Baeza et al. 2001). Furthermore, while the free living closest relatives of $A$. spinifrons inhabit their refuges as unstructured aggregations, A. spinifrons feature a solitary lifestyle (Baeza et al. 2001). This solitary habit is due to the territorial behavior of adult individuals, and most probably is an adaptation to host scarcity (Baeza \& Thiel 2003, Baeza et al. 2002). Thus, indeed, the adoption of a symbiotic lifestyle may have important consequences on the social behavior of symbionts depending upon habitat characteristics.

In summary, it has been shown that symbiosis between marine crabs from the genus Petrolisthes and other macroinvertebrates evolved at least twice in the eastern Pacific. Competition, thought to be important in explaining the evolution of symbiosis in marine invertebrates, apparently did not play a role in the origins of this trait as suggested by the present comparative analysis. The present study further suggests that on occasion, depending upon characteristics of the host species, the adoption of a symbiotic life-style may have important consequences for the social life of the symbionts. Symbiotic crabs in the family Porcellanidae are proposed as a model system with which to explore the importance of habitat characteristics in determining the evolution of behavioral traits (i.e. resource-guarding behavior, mating system) in symbiotic crustaceans.

\section{Acknowledgments}

Thanks to Darryl Felder, Suzanne Frederick, Jonathon Stillman, Jodi Caskey, and Amanda Windsor for commenting on preliminary versions of the present manuscript. The comments of two anonymous reviewers substantially improved the present manuscript.

\section{Literature cited}

Achituv Y \& ML Pedrotti. 1999. Costs and gains of porcelain crab suspension feeding in different flow conditions. Marine Ecology Progress Series 184: 161169.

Antezana T, E Fagetti \& MT Lopez. 1965. Observaciones bioecológicas en decápodos comunes de Valparaíso. Revista de Biología Marina, Valparaíso 12: 1-60.

Baeza JA \& M Thiel. 2000. Host use pattern and life history of Liopetrolisthes mitra, an associate of the black sea urchin Tetrapygus niger. Journal of the Marine Biological Association of the United Kingdom 80: 39-45.

Baeza JA \& M Thiel. 2003. Predicting territorial behavior in symbiotic crabs using host characteristics: A comparative study and proposal of a model. Marine Biology 142: 93100.

Baeza JA \& WB Stotz. 1998. Selección del hábitat durante el asentamiento larval de Allopetrolisthes spinifrons (H.Milne Edwards, 1837) (Decapoda: Anomura: Porcellanidae), un cangrejo comensal de la anémona Phymactis clematis (Drayton, 1798) (Coelenterata: Anthozoa). Revista de Biología Marina y Oceanografía 33: 331-343.

Baeza JA \& WB Stotz. 2003. Host-use and selection of differently-colored sea anemones by the symbiotic crab Allopetrolisthes spinifrons. Journal of Experimental Marine Biology and Ecology 284: 25-39.

Baeza JA, WB Stotz \& M Thiel. 2002. The agonistic behaviour and development of territoriality during ontogeny of the sea anemone dwelling crab Allopetrolisthes spinifrons. Marine and Freshwater Behaviour and Physiology 35: 189-202.

Baeza JA, M Thiel \& WB Stotz. 2001. The life history of Allopetrolisthes spinifrons, a crab associate of the sea anemone Phymactis clematis. Journal of the Marine Biological Association of the United Kingdom 81: 69-76.

Bloom SA. 1975. Motile escape response of a sessile prey. Sponge-scallop mutualism. Journal of Experimental Marine Biology and Ecology 17: 311-321.

Boltaña S \& M Thiel. 2001. Associations between two species of snapping shrimp, Alpheus inca and Alpheopsis chilensis (Decapoda: Caridea: Alpheidae). Journal of the Marine Biological Association of the United Kingdom 81: 633-638.

Brusca RC. 1980. Common intertidal invertebrates of the Gulf of California. $2^{\text {nd }}$ ed. The University of Arizona Press, Tucson. 
Campos-Gonzáles E \& LJ Macías-Chávez. 1987. Fases postplanctónicas de Petrolisthes armatus (Gibbes) (Decapoda, Porcellanidae) comensales con la lapa Crucibulum (Crucibulum) spinosum (Sowerby) (Gastropoda, Calyptraeidae) en el Alto Golfo de California, México. Revista de Biología Tropical 35: 241244.

Carvacho A. 1985. Los Porcelánidos del Pacífico Americano: Un análisis biogeográfico (Crustacea: Decapoda). Anales del Centro de Ciencias Marinas y Limnología, Universidad Nacional Autónoma de México 7: $249-258$

Correa-Sandoval F \& DE Rodríguez-Cortéz. 1998. Análisis de la distribución geográfica de los anomuros (Crustacea: Decapoda) del Golfo de California, México. Journal of Biogeography 25: 1133-1144.

Cunningham CW, LW Buss \& C Anderson. 1991. Molecular and geologic evidence of shared history between hermit crabs and the symbiotic genus Hydractinia. Evolution 45: 1201-1316.

Distel DL, H Felbeck \& CM Cavanaugh. 1994. Evidence for phylogenetic congruence among sulfur-oxidizing chemoautotrophic bacterial endosymbionts and their bivalve hosts. Journal of Molecular Evolution 38: 533542.

Duffy JE, CL Morrison \& R Ríos. 2000. Multiple origins of Eusociality among sponge-dwelling shrimps (Synalpheus). Evolution 54: 503-516.

Erpenbeck D, JAJ Breeuwer, HC van der Velde \& RWM van Soest. 2002. Unravelling host and symbiont phylogenies of halichondrid sponges (Demospongiae, Porifera) using a mitochondrial marker. Marine Biology 141: 377-386.

Felsenstein J. 1985. Phylogenies and the comparative method. American Naturalist 125: 1-15.

García-Madrigal M. 1999. Anomuros (Anomura) del arrecife de Cabo Pulmo-Los Frailes y alrededores, Golfo de California. Revista de Biología Tropical 47: 917-923.

Gast RJ \& DA Caron.1996. Molecular phylogeny of symbiotic dinoflagellates from planktonic foraminifera and radiolarian. Molecular Biology and Evolution 9: 1192-1197.

Geller JB \& ED Walton. 2001. Breaking up and getting together: evolution of symbiosis and cloning by fission in sea anemones (genus Anthopleura). Evolution 55: 17811794.

Giannasi N, RS Thorpe \& A Malhotra. 2000. A phylogenetic analysis of body size evolution in the Anolis roquet group (Sauria: Iguanidae): character displacement or size assortment? Molecular Ecology 9: 193-202.
Gore RH. 1982. Porcellanid Crabs from the Coasts of Mexico and Central America (Crustacea: Decapoda: Anomura). Smithsonian Contributions to Zoology 363: 134.

Gore RH \& LG Abele. 1976. Shallow water porcelain crabs from the Pacific coast of Panama and adjacent Caribbean water (Crustacea, Anomura, Porcellanidae). Smithsonian Contributions to Zoology 237: 1-30.

Griffith H. 1987. Phylogenetic relationships and evolution in the genus Dissodactylus Smith, 1870 (Crustacea: Brachyura: Pinnotheridae). Canadian Journal of Zoology 65: 2292-2310.

Haig J. 1960. The Porcellanidae (Crustacea, Anomura) of the Eastern Pacific. Allan Hancock Pacific Expeditions 24: 1440.

Haig J. 1968. Eastern Pacific Expeditions of the New York Zoological Society. Porcellanid crabs (Crustacea: Anomura) from the West Coast of Tropical America. Zoologica, New York 53: 57-74.

Harvey PH \& MD Pagel. 1991. The comparative method in evolutionary biology. 239 pp. Oxford University Press, Oxford.

Hiller A, H Kraus, M Almon \& B Werding. 2006. The Petrolisthes galathinus complex: Species boundaries based on color pattern, morphology and molecules, and evolutionary interrelationships between this complex and other Porcellanidae (Crustacea: Decapoda: Anomura). Molecular Phylogenetics and Evolution 40: 547-569.

Jensen GC \& DA Armstrong. 1991. Intertidal zonation among congeners: factors regulating the distribution of porcelain crabs, Petrolisthes spp. (Anomura: Porcellanidae). Marine Ecology Progress Series 73: 4761.

Kropp RK. 1981. Additional porcelain crab feeding methods (Decapoda, Porcellanidae). Crustaceana 40: 307-310.

Langer MR \& JH Lipps. 1995. Phylogenetic incongruence between dinoflagellate endosymbionts (Symbiodinium) and their host foraminifera (Sorites): small-subunit ribosomal RNA gene sequence evidence. Marine Micropaleontology 26: 179-186.

Losos JB. 1990. A phylogenetic analysis of character displacement in Caribbean Anolis lizards. Evolution 44: 558-569.

Maddison DR \& WP Maddison. 2000. MacClade 4: Analysis of Phylogeny and Character Evolution, version 4.0. Sinauer Associates, Sunderland.

Purvis A \& A Rambaut. 1995. Comparative analysis by independent contrasts (CAIC) - an Apple-Macintosh application for analyzing comparative data. Computer Applications in the Biosciences 11: 247-251. 
Ricketts EF, J Calvin, JW Hedgpeth \& DW Phillips. 1985. Between Pacific Tides. 652 pp. $5^{\text {th }}$ ed. Stanford University Press, Stanford.

Ross DM. 1983. Symbiotic relations. In: SJ Vernberg \& WB Vernberg (eds), The Biology of Crustacea 7: 163-212. Academic Press, New York.

Roughgarden J. 1975. Evolution of marine symbiosis - a simple cost-benefit model. Ecology 56: 1201-1208.

Roughgarden J. 1982. The evolution of resource partitioning in a multidimensional resource space. Theoretical Population Biology 22: 127-145.

Roughgarden J. 1983a. Coevolution between Competitors. In: DJ Futuyma \& M. Slatkin (eds). Coevolution, pp. 383403. Sinauer Associates, Sunderland.

Roughgarden J. 1983b. Competition and theory in community ecology. American Naturalist 122: 583-601.

Schluter D. 1996. Ecological causes of adaptive radiations. American Naturalist 148 (Supplement): S40-S64.

Stillman JH \& CA Reeb. 2001. Molecular phylogeny of eastern Pacific porcelain crabs, genera Petrolisthes and Pachycheles, based on the mtDNA 16S rDNA sequence: phylogeographic and systematic implications. Molecular Phylogenetics and Evolution 19: 236-245.

Stuardo J. 1962. El comensalismo de Allopetrolisthes spinifrons (H. Milne Edwards). Gayana, Zoología 6: 5-9.

Swofford DL. 2002. PAUP*: Phylogenetic Analysis Using Parsimony (and other methods), version 4.010b. Sinauer Associates, Sunderland.

Thiel M \& JA Baeza. 2001. Factors affecting the social behaviour of symbiotic Crustacea: a modelling approach. Symbiosis 30: 163-190.

Thiel M, A Zander, N Valdivia, JA Baeza \& C Rueffler. 2003. Host fidelity of a symbiotic porcellanid crab: the importance of host characteristics. Journal of Zoology 261: 353-362.

Valdivia N \& W Stotz. 2006. Feeding behavior of the porcellanid crab Allopetrolisthes spinifrons, symbiont of the sea anemone Phymactis papillosa. Journal of Crustacean Biology 26: 308-315.

Vance RR. 1978. A mutualistic interaction between a sessile marine clam and its epibionts. Ecology 59: 679-685.

Vermeij GJ. 1983. Intimate Associations and Coevolution in the Sea. In: DJ Futuyma \& M Slatkin (eds). Coevolution, pp. 311-327. Sinauer Associates, Sunderland.

Villarroel H. 1989. Coexistencia, repartición de hábitats y alimento en crustáceos porcelánidos. Tesis de Biología Marina, Facultad de Ciencias del Mar, Universidad Catolica del Norte, Coquimbo, 75 pp.

Villalobos JL, JC Nates, A Cantú, MD Valle, P Flores, E Lira \& P Schmidtsdorf. 1989. Listados faunísticos de México. I. Crustáceos estomatópodos y decapodos intermareales de las Islas del Golfo de California, México. Instituto de Biología, Universidad Nacional Autónoma de México. Pp. 1-114.

Viviani CA. 1969. Los Porcellanidae (Crustacea, Anomura) chilenos. Beitrage zur Neotropischen fauna 6: 1-14.

Weber LI. 1991. Sinonimia y caracterización de Liopetrolisthes mitra (Dana, 1852) y Liopetrolisthes patagonicus (Cunningham, 1871) N. Comb. (Crustacea, Porcellanidae). Gayana, Zoología 55: 13-22.

Weber LI \& R Galleguillos. 1991. Morphometric and electrophoretic evidences for two species of the genus Liopetrolisthes (Crustacea, Decapoda, Porcellanidae) and some aspects of their variability. Comparative Biochemistry and Physiology B 100: 201-207.

Weis VM, WS Reynolds, MD deBoer \& DA Krupp. 2001. Host-symbiont specificity during onset of symbiosis between the dinoflagellates Symbiodinium spp. and planula larvae of the scleractinian coral Fungia scutaria. Coral Reefs 20: 301-308.

Werding B \& J Haig. 1983. The porcellanid crabs of the Isla Gorgona, Pacific Coast of Colombia, with a description of Clastotoechus gorgonensis sp. nov. (Crustacea: Anomura). Anales del Instituto de Investigaciones Marinas de Punta Betín 12: 57-70.

Recibido el 17 de abril de 2006 y aceptado el 19 de octubre de 2006 